\title{
Physicochemical, in vitro and in vivo evaluation of flurbiprofen microemulsion
}

\author{
MUHAMMAD NAEEM ${ }^{1,2}$, NISAR UR RAHMAN ${ }^{1,2}$, GUILHERME. D. TAVARES ${ }^{3}$, SÁVIO F. BARBOSA ${ }^{4}$, \\ NÁDIA B. CHACRA ${ }^{4}$, RAIMAR LÖBENBERG ${ }^{5}$ and MUHAMMAD K. SARFRAZ ${ }^{5}$ \\ ${ }^{1}$ Department of Pharmacy, Faculty of Pharmacy and Alternative Medicine, \\ The Islamia University of Bahawalpur, Punjab, 63100, Pakistan \\ ${ }^{2}$ Department of Pharmacy, COMSATS Institute of Information Technology, \\ University Road, 22060, Abbottabad, KPK, Pakistan \\ ${ }^{3}$ Department of Biochemistry, Institute of Biology, State University of Campinas, 13083-862 Campinas, SP, Brazil \\ ${ }^{4}$ Faculty of Pharmaceutical Sciences, Department of Pharmacy, University of Sao Paulo, 05508-000 São Paulo, SP, Brazil \\ ${ }^{5}$ Faculty of Pharmacy and Pharmaceutical Sciences, Katz Group-Rexall Centre for Pharmacy and Health Research, \\ University of Alberta, 11361-87 Avenue, Edmonton, Alberta, T6G 2E1, Canada
}

Manuscript received on November 6, 2013; accepted for publication on May 18, 2015

\begin{abstract}
Flurbiprofen, a potent nonsteroidal anti-inflammatory drug, is widely used for relief of pain in patients suffering from rheumatic diseases, migraine, sore throat and primary dysmenorrheal. However, this drug has many gastrointestinal side effects produced by its oral administration, such as gastric bleeding and peptic ulcer. These effects were responsible for non-compliance among patients, which ultimately results in treatment failure. The physicochemical properties of flurbiprofen, make it a suitable candidate for transdermal drug delivery, which can overcome the drawbacks of oral administration. In this sense, microemulsions have been proved to increase the cutaneous absorption of lipophilic drugs when compared to conventional drug delivery systems. The purpose of this study was to formulate and characterize gel based microemulsions, for topical delivery of flurbiprofen. Different gel bases, containing microemulsion and hydro-alcoholic solution of flurbiprofen, were developed and compared. In vitro study showed that gels containing microemulsion had a higher permeation rate than those containing hydro-alcoholic solutions. Additionally, formulation of Carbopol-I (microemulsion) showed higher percent of inhibition of inflammation than others bases. Further, skin irritation study demonstrated that Carbopol-I was none irritating. Flurbiprofen microemulsion incorporated on Carbopol-I showed physicochemical, in vitro and in vivo characteristics suitable for the development of alternative transdermal delivery formulation.
\end{abstract}

Key words: anti-inflammatory study, flurbiprofen, gels, In vitro permeation, microemulsion.

\section{INTRODUCTION}

Flurbiprofen is used in inflammation, rheumatic diseases and mild to moderate pain of migraine, sore throat and also in primary dysmenorrheal (British National Formulary 2006, Schachtel et al.

Correspondence to: Nisar-Ur-Rahman

E-mail: nisar@ciit.net.pk
2014). Many gastrointestinal side effects caused due to the presence of free carboxylic acid group (Figure 1), are produced by its oral administration, such as dyspepsia, cramping, gastric bleeding and peptic ulcer, causing non-compliance among patients, which ultimately results in treatment failure (Mishra et al. 2008). 


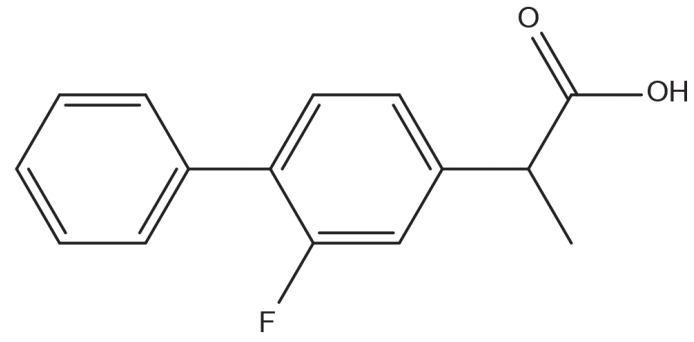

Figure 1 - Chemical Structure of Flurbiprofen.

The physicochemical properties of flurbiprofen, i.e., lipophilicity, low molecular weight and short elimination half-life make it a suitable candidate for transdermal drug delivery, which can overcome the drawbacks of oral administration (Fang et al. 2003). However, it's very low aqueous solubility hinders the skin permeation. Thus, it is imperative to develop novel drug delivery systems aimed to improve its skin permeation and therapeutic compliance.

In this sense, microemulsions have been proven to increase the cutaneous absorption of lipophilic drugs when compared to conventional vehicles (Nisha et al. 2011). Microemulsions are fluid, transparent, thermodynamically stable oil and water systems, stabilized by a surfactant usually in conjunction with a cosurfactant that could be a short-chain alcohol, amine, or other weakly amphiphilic molecule. An interesting characteristic of microemulsions is that the diameter of the droplets is in the range of $100-1000 \mathrm{~A}^{\circ}$, whereas the diameter of droplets in a kinetically stable macroemulsion is $5000 \mathrm{~A}^{\circ}$. The small droplet size allows the microemulsion to act as carriers for drugs that are poorly soluble in water (Zhu et al. 2009). The suggested method of preparation of microemulsions is as follows: the surfactant, oil and water are mixed, to form a milky emulsion, and titrated with a fourth component, the co-surfactant, until the mixture becomes clear. If more oil is added to a water/oil (w/o) system, the system becomes cloudy, but the addition of more co-surfactant again gives a clean transparent emulsion (Betageri and Prabhu 2007, Fouad et al. 2013).
In the present study, the polymer based gel containing microemulsion or hydro-alcoholic solution were formulated using Carbopol 934P and Xanthan gum as gelling agents and were characterized on the basis of $\mathrm{pH}$, viscosity, conductivity and thermodynamic stability study. In vitro permeation through excised rabbit skin and in vivo anti-inflammatory activity were also investigated. Furthermore 934P based gel containing microemulsion was evaluated for skin irritation.

\section{MATERIALS AND METHODS}

The following materials were received and used: Flurbiprofen (Hamaz, Pakistan), Oleic acid (Merck, Germany), Tween 20 (Fisher Scientific, UK) Propylene glycol (Merck, Germany), Ethanol (Merck, Germany), Potassium dihydrogen orthophosphate (Merck, Germany), Sodium hydroxide pellets (Merck, Germany), Xanthan Gum (CCL Lahore), Carbopol 934P (Wilson, Islamabad), Triethanol amine (Merck, Germany), Methyl and Propyl paraben (Merck, Germany), Water Soluble Tetrazolium-1 (Dojindo Laboratories, Kumamoto, Japan), Zymosan A (Sigma Chemicals, St Louis, MO, USA).

\section{PREPERATION OF MICROEMULSION AND HYDRO-ALCOHOLIC} SOLUTION OF FLURBIPROFEN

Flurbiprofen loaded microemulsion obtained by a simplex lattice experiment design in our previous study was comprised of $5 \%(\mathrm{w} / \mathrm{w})$ flurbiprofen, $5 \%(\mathrm{w} / \mathrm{w})$ oleic acid, 46\% (w/w) Tween 20:ethanol $(2: 1)$ and $44 \%(\mathrm{w} / \mathrm{w})$ water (Idress et al. 2011). The preparation method was as follows, Oil and Smix (surfactant + cosurfactant, 2:1) were mixed vigorously under constant stirring. A known amount of flurbiprofen was added to this oily phase and mixed until completely dissolved. Then an appropriate amount of distilled water was added slowly under constant stirring at room temperature. The microemulsions were stored at room temperature (Chen et al. 2006). 
For hydro-alcoholic solution, flurbiprofen was dissolved in ethanol and mixed well until completely dissolved. Then distilled water was added in alcoholic drug solution to form hydroalcoholic solution under gentle mixing.

Preperation of CARbopol and Xanthan Gum Based Gels CONTAINING MicRoemulsion AND Hydro-AlCOHOLIC SOLUTION

The first step consisted of Carbopol gel bases containing $0.70,0.80,0.90,1.00,1.10$ and $1.20 \%$ $\mathrm{w} / \mathrm{w}$ were prepared by gradually dissolving Carbopol 934P in specific amounts of distilled water, at room temperature, under constant stirring. Triethanol amine was added to adjust the $\mathrm{pH}$ between 6 to 7 . From the different bases, that containing Carbopol $1 \%(\mathrm{w} / \mathrm{w})$ was found to have optimum viscosity and was thus selected for further studies.

Xanthan gel bases containing 1.10, 1.20, 1.30, $1.40,1.50$ and $1.60 \%$ were prepared by first dissolving the gum in specific amounts of distilled water at room temperature under constant stirring. The methyl and propyl paraben were then added as preservatives. From the different bases, those containing $1 \%(\mathrm{w} / \mathrm{w})$ and $1.5 \%(\mathrm{w} / \mathrm{w})$ of Carbopol $934 \mathrm{P}$ and Xanthan gum respectively, were found to have optimum viscosity and selected for further studies.

In second step microemulsion or hydroalcoholic solution of flurbiprofen were added separately to the $1 \%(\mathrm{w} / \mathrm{w})$ Carbopol $934 \mathrm{P}$ and $1.5 \%(\mathrm{w} / \mathrm{w})$ Xanthan gum to make Carbopol 934P and Xanthan gum based gels and mixing was done at room temperature.

\section{CHARACTERIZATION OF GEL BASES AND MiCROEMULSION}

Brookfield RVDV III ultra, Programmable Rheometer (Brookfield Engineering Laboratories, Middleboro, MA) was used to determine the viscosities by using ULA (Ultra Low Adaptor) under a temperature of $25{ }^{\circ} \mathrm{C}$. Conductometer WTW Cond 197i (Weilhein, Germany) was used to determine the conductivities $(\sigma)$ under a temperature of $25^{\circ} \mathrm{C}$ (Djordjevic et al. 2005). $\mathrm{pH}$ meter (WTW inolab, Germany) was used to measure the $\mathrm{pH}$ values under a temperature of $25^{\circ} \mathrm{C}$. The analyses were performed in triplicate.

\section{THERMODYNAMIC STABILITY TESTS}

The selected formulations of Carbopol and Xanthan were kept for 3 months at $40{ }^{\circ} \mathrm{C}$ and centrifuged at $10,000 \mathrm{rpm}$ for $15 \mathrm{~min}$ to check physical stability. Furthermore, these formulations were also evaluated at $25{ }^{\circ} \mathrm{C}$ for $\mathrm{pH}$ changes, visual clarity, viscosity, conductivity and assessment of drug using UV assay.

\section{IN VITRO SKIN PERMEATION RELEASE RATE}

Skin samples were obtained from the dorsal region of rabbit after removing hair with razor (Chen et al. 2006). Heat separation was used to remove epidermis and scalpel was used to remove subcutaneous fat (Shah et al. 2006, Pellet et al. 1997). Diffusion cells of Vertical Franz type (PermeGear, Bethlehem, PA) were used with diffusional surface area of 1.767 $\mathrm{cm}^{2}$. The receptor compartment, with capacity of 12 $\mathrm{ml}$, contained the phosphate buffer solution (PBS) at $7.4 \mathrm{pH}$. The skin was placed between the donor and receptor compartments of the cell (Ozguney et al. 2006). Water bath and a peristaltic pump were used to maintain the temperature of the receptor solution at $37^{\circ} \mathrm{C}$. Teflon-coated magnet bar was used for stirring. The concentration of the selected formulations was $1.0 \mathrm{~g}$ that was applied to donor compartment. After pre-determined time intervals (0 to 24 hours), $1 \mathrm{ml}$ of the sample was removed from the receptor compartment for UV determination and immediately replaced with an equal quantity of fresh PBS. There was no interference of the components. These dose conditions are infinite (Roessler et al. 2001).

The cumulative amount of flurbiprofen was plotted as a function of time through excised rabbit skin. The permeation release rate of flurbiprofen was calculated from the slope and intercept of the 
straight line by plotting the amount of flurbiprofen permeated versus the time in steady state conditions. Permeation coefficient was calculated by dividing the flux by the flurbiprofen concentration of the donor compartment.

\section{ANTI-INFLAMMATORY ACTIVITY ASSAY}

The method for the isolation of human neutrophils was established (Kantarci et al. 2007). The antiinflammatory activity of polymer based gel formulations was assayed (Siddiqui et al. 1995). In this in vitro study, Opsonised Zymosan A was used to activate the neutrophils. These activated neutrophils were used for the reduction of water soluble tetrazolium salt. The anti-inflammatory activity was determined by using Carbopol and Xanthan gum based gels containing microemulsion or hydro-alcoholic solution, water soluble tetrazolium salt in concentration of $250 \mu \mathrm{m}$ and Modified Hank's Solution (MHS) of $\mathrm{pH} 7.4$ in concentration of $200 \mu \mathrm{l}$ containing 1.0-104 neutrophils $/ \mathrm{ml}$. The control consisted of water soluble tetrazolium salt, buffer and neutrophils. The Opsonised Zymosan A $(15 \mathrm{mg} / \mathrm{ml})$ was added to initiate a reaction of test compounds. Absorbance was taken at $450 \mathrm{~nm}$. The formula for percent of inhibition is given below. The software used was EZ-FIT Windows-based software.

$\%$ Inhibition $=100-\{($ Optical density of formulation / Optical density of control) $\times 100\}$.

\section{IN VIVO SKIN IRRITATION STUDY}

The screened Carbopol 934P based gel containing microemulsion was applied to the inner arms of 10 human volunteers aged between 21-27 years, by placing gel on gauze dressing $\left(1 \times 1 \mathrm{~cm}^{2}\right)$. Stretch adhesive tape was used for fixing the gel on the inner arm. The reading was taken after $8 \mathrm{~h}$ (OECD 2004).

\section{STATISTICAL ANALYSIS}

Two-way analysis of variance (ANOVA) was used to measure the skin permeation release rate. For the study of skin irritation, statistical paired sample $t$-test was used at the level of $P=0.05$. These tests were performed by SPSS 12.0 software.

\section{ETHICAL STANDARDS}

Ethical approval for different bases containing flurbiprofen microemulsion studies was granted by the Islamia University of Bahawalpur, Pakistan and Institutional ethical committee. The informed consent was filled by the patients before the test.

\section{RESULTS}

Characterization OF Gel Bases AND Microemulsion

A number of gel bases were prepared by using different concentrations of Carbopol 934P and Xanthan gum. The viscosities of Carbopol 934P $(0.70-1.20 \% \mathrm{w} / \mathrm{w})$ and Xanthan gum $(1.10-1.60 \%$ $\mathrm{w} / \mathrm{w})$ gel bases were in the range of $307-1522 \mathrm{cp}$ and 151-460 cp respectively. The conductivities of Carbopol 934P (0.70-1.20\% w/w) and Xanthan gum $(1.10-1.60 \% \mathrm{w} / \mathrm{w})$ gel bases were in the range of 322-1293 and 405-1360 microsiemens/ $\mathrm{cm}$ respectively. The $\mathrm{pH}$ values of Carbopol 934P $(0.70-1.20 \% \mathrm{w} / \mathrm{w})$ and Xanthan gum $(1.10-1.60 \%$ $\mathrm{w} / \mathrm{w})$ gel bases were in the range of 6.00-6.11 and 6.13-6.25 respectively. The Carbopol 934P and Xanthan gum gel bases of $0.7 \%$ and $1.10 \%(\mathrm{w} / \mathrm{w})$ respectively had high fluidity while the Carbopol 934P and Xanthan gum gel bases of $1.20 \%$ and $1.60 \%(\mathrm{w} / \mathrm{w})$ respectively had high viscosity.

\section{THERMODYNAMIC STABILITY STUDY}

As the Carbopol 934P and Xanthan gum gel bases of $1.00 \%$ and $1.50 \%$ respectively had suitable fluidity and viscosity therefore, these were selected for further studies. Stability study showed that the selected gel bases containing microemulsion (Carbopol-I and Xanthan-I) and gel bases containing hydro-alcoholic solution (CarbopolII and Xanthan-II) were physically stable. The formulations were stable at $40^{\circ} \mathrm{C}$ and no phase 
separation and degradation of flurbiprofen were observed during the 3 months study. The viscosity, conductivity and $\mathrm{pH}$ of these gel formulations and the microemulsion after thermodynamic stability test are shown in Table I.

\section{IN VITRO PERMEATION SKIN RELEASE STUDY}

The cumulative amount of flurbiprofen after $24 \mathrm{~h}$ of applying microemulsion, Carbopol-I, Xanthan-I, Carbopol-II and Xanthan-II was 572.01, 476.40, 436.62, 135.59 and $132.61 \mu \mathrm{g} / \mathrm{cm}^{2}$ respectively. The in vitro skin permeation showed a steady increase in concentration of flurbiprofen in the receptor chamber with time (Figure 2). The permeation release rate was highest for microemulsion and lowest for both Carbopol-II and Xanthan-II.

The transdermal flux was calculated from permeation release rate and the permeation coefficient was calculated from transdermal flux values. Then the results were analyzed by two-way ANOVA with level of significance of 0.05 . The transdermal flux of microemulsion, Carbopol-I, Xanthan-I, CarbopolII and Xanthan-II was 18.75, 15.72, 9.80, 4.76 and $2.70 \mu \mathrm{g} / \mathrm{cm}^{2} / \mathrm{h}$ respectively after 24 hour. In the same way, the permeability coefficient of microemulsion, Carbopol-I, Xanthan-I, Carbapol-II and XanthanII was $0.38,0.31,0.19,0.09$ and $0.05 \mu \mathrm{g} / \mathrm{cm}^{2} / \mathrm{h}$ respectively after $24 \mathrm{~h}$ (Table II).

TABLE I

Physicochemical parameters of microemulsions, Carbopol 934P and Xanthan gum based gels containing microemulsions and hydro-alcoholic solution after 3 months at $40{ }^{\circ} \mathrm{C}$. All measurements were done at $25^{\circ} \mathrm{C}$.

\begin{tabular}{ccccc}
\hline Sr. No. & Formulation Code & Viscosity $(\mathbf{c p})$ & Conductivity $(\boldsymbol{\sigma})(\boldsymbol{\mu S} / \mathbf{c m})$ & $\mathbf{p H}$ \\
\hline $\mathbf{1}$ & Carbopol-I & 400 & 387 & 6.09 \\
$\mathbf{2}$ & Xanthan-I & 280 & 485 & 6.16 \\
$\mathbf{3}$ & Carbopol-II & 270 & 470 & 6.05 \\
$\mathbf{4}$ & Xanthan-II & 190 & 655 & 6.15 \\
$\mathbf{5}$ & Microemulsion & 55 & 145.5 & 5.01 \\
\hline
\end{tabular}

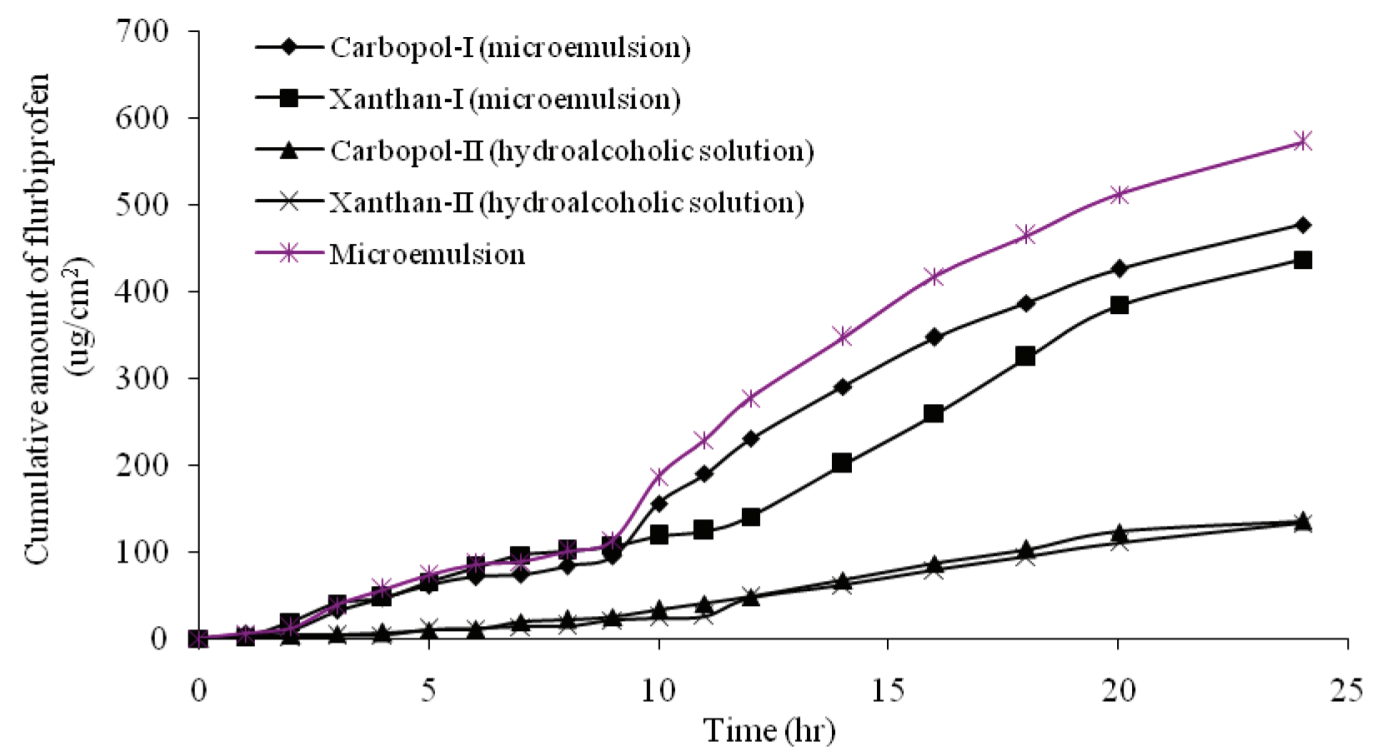

Figure 2 - Comparison of Permeation profile of Flurbiprofen through excised rabbit skin of Microemulsion and; Carbopol 934P and Xanthan gum based gel containing microemulsion and hydro-alcoholic solution. Mean \pm S.D. $(n=3)$. 
TABLE II

Permeation parameters of Carbopol 934P and Xanthan

Gum based gels containing microemulsions and hydroalcoholic solutions. Mean \pm S.D. $(\mathbf{n}=\mathbf{3})$.

\begin{tabular}{|c|c|c|c|}
\hline Sr. No. & Formulation Codes & Flux, Jss $\left(\mu \mathrm{g} / \mathrm{cm}^{2} / \mathrm{h}\right)$ & $\begin{array}{c}\text { Permeability Coefficient } \\
\mathrm{Kp} \times 10^{-3}(\mathrm{~cm} / \mathrm{h})\end{array}$ \\
\hline 1 & Carbopol-I & $15.72 \pm 0.05$ & $0.31 \pm 0.041$ \\
\hline 2 & Xanthan-I & $9.80 \pm 0.09$ & $0.19 \pm 0.017$ \\
\hline 3 & Carbopol-II & $4.76 \pm 0.07$ & $0.09 \pm 0.011$ \\
\hline 4 & Xanthan-II & $2.70 \pm 0.05$ & $0.05 \pm 0.007$ \\
\hline 5 & Microemulsion & $18.75 \pm 0.08$ & $0.38 \pm 0.045$ \\
\hline
\end{tabular}

The permeation release rate of microemulsion, Carbopol-I, Xanthan-I, Carbopol-II and Xanthan-II were measured by two-way ANOVA with level of significance of 0.05 and the measured value of $\mathrm{P}$ was less than 0.05 .

\section{ANTI-INFLAMMATORY STUDY}

The results of anti-inflammatory study of Carbopol-I, Xanthan-I, Carbopol-II and Xanthan-II are given in Table III. The percent of inhibition of inflammation was highest for gel bases containing the microemulsion and lowest for both containing hydro-alcoholic solution.

\section{IN VIVO SKIN IRRITATION STUDY}

Erythema values before and after the application of Carbopol-I were noted and are given in Table IV. Statistical pair sample t-test was used to analyze the results, with level of significance of 0.05 and $\mathrm{p}=0.05$. No significant increase in erythema values was observed after $8 \mathrm{~h}$ of application.

\section{TABLE III}

Percent of inhibition of inflammation of polymer based gel containing microemulsion (Carbopol-I and Xanthan-I) and hydro-alcoholic solution of flurbiprofen (Carbopol-II and Xanthan-II).

\begin{tabular}{ccc}
\hline S. No & Formulations & \% Inhibition \\
\hline 1 & Carbopol-I & 57 \\
2 & Xanthan-I & 45 \\
3 & Carbopol-II & 25 \\
4 & Xanthan-II & 15 \\
\hline
\end{tabular}

TABLE IV

Erythema values before (control) and after the application of Carbopol-I on 10 human volunteers.

\begin{tabular}{ccc}
\hline No. of Volunteer & Control & After 8 h of Application \\
\hline $\mathbf{1}$ & 421 & 425 \\
$\mathbf{2}$ & 250 & 241 \\
$\mathbf{3}$ & 330 & 335 \\
$\mathbf{4}$ & 365 & 370 \\
$\mathbf{5}$ & 200 & 210 \\
$\mathbf{6}$ & 235 & 240 \\
$\mathbf{7}$ & 260 & 263 \\
$\mathbf{8}$ & 420 & 412 \\
$\mathbf{9}$ & 410 & 415 \\
$\mathbf{1 0}$ & 490 & 493 \\
\hline
\end{tabular}

\section{DISCUSSION}

Carbopol 934P and Xanthan gum was used to prepare gel bases in different concentrations. In preparing gels, the color of the final formulation was turned white. This was caused by dehydration of some of the ingredients like surfactant and cosurfactant of microemulsion, which results in dissociation of polymers from hydrated state.

Incorporation of polymers into microemulsion and addition of microemulsion into the gel bases were used to formulate polymer based gel. In direct addition of polymer to the microemulsion, more time was consumed for the swelling of polymer. A non-homogeneous gel containing microemulsion was formed due to incomplete swelling of polymer and formation of small agglomerates. The gel base was first prepared in which the whole amount of polymer was completely swelled in aqueous phase. 
The known amount of microemulsion was mixed gradually into the gel base. Complete swelling with no agglomerates was observed due to complete swelling of polymer (Tan and Berridge 2000).

The Carbopol 934P and Xanthan gum gel bases of 1.00 and $1.50 \%(\mathrm{w} / \mathrm{w})$ respectively had suitable fluidity and viscosity for the topical delivery system. Thus, these gel bases were used for the preparation of gels containing microemulsion or hydro-alcoholic solution of flurbiprofen. The high conductivity indicated Oil/Water $(\mathrm{O} / \mathrm{W})$ microemulsion and the $\mathrm{pH}$ values near 7 could be resulted in less irritation to skin. The intracellular and transcellular micropathways play a vital role in the permeation of drug through stratum corneum. The intracellular pathway has higher percutaneous absorption than that of transcellular. The physicochemical properties of microemulsion and stratum corneum were studied to check the permeability enhancing ability of microemulsion and efficiency for percutaneous absorption. The polar and lipid pathways are changed when oily phase of microemulsion containing drug enter the stratum corneum of the skin. The oily phase of microemulsion can interact with skin in a number of ways. The oily phase of microemulsion containing drug can directly partition into the lipids of stratum corneum. This changes the bilayer structure of skin. The intracellular volume of stratum corneum can be increased by the oily phase of microemulsion, which in turn changes the interfacial structure. The permeation of hydrophobic drug can be increased by disruption of lipid layers caused by swelling of proteins (Chen et al. 2007).

Carbopol-I showed intermediate permeation release rate between microemulsion and Xanthan-I. Release rate of microemulsion is higher than Carbopol-I which is due to the presence of oleic acid and ethanol in microemulsion. This in turn reduce the barrier function of the stratum corneum and enhance the permeability coefficient of flurbiprofen through skin. The results showed that the addition of polymer to microemulsion decrease the permeability of flurbiprofen by increasing the viscosity and transform from microemulsion to the lamellar structure or a highly ordered microstructure (Hire et al. 2007, Trotta 1999, Peltota et al. 2003). Additionally, the permeation release rate of microemulsion, Carbopol-I, Xanthan-I, CarbopolII and Xanthan-II showed that the transdermal flux of these formulations are significantly different from each other (ANOVA, $\mathrm{P}<0.05$ ). It is clear from all the formulations that the transdermal flux of microemulsion and polymer based gels containing microemulsion was greater than that of polymer based gels containing hydro-alcoholic solution.

In relation to anti-inflammatory study, a significant increase in the percent of inhibition of inflammation was observed for gel bases containing microemulsion (Carbopol-I and Xanthan-I) as compared to gel bases containing hydro-alcoholic solution (Carbopol-II and Xanthan-II). Moreover, droplet sizes of microemulsion used in both Carbopol-I and Xanthan-I was smaller and thus provides more opportunities for drug transferring into the skin improving its transdermal flux and pharmacologic activity (Khurana et al. 2013, Okur et al. 2014).

Although microemulsion had higher permeation release rate, but its use is limited due to having low $\mathrm{pH}$ which might produce skin irritation and comparatively less adherence to the skin. Therefore, adherence and $\mathrm{pH}$ of microemulsion could be increased by incorporation of Carbopol 934P. Therefore, the formed Carbopol 934P based gel containing microemulsion (Carbopol-I) had $\mathrm{pH}$ in the range of 6-7 which is non-irritating and more adhering to the skin to produce intermediate permeation release rate with sustained effect. Carbopol-I had higher transdermal flux and percent of inhibition of inflammation as compared to Xanthan-I. Consequently, Carbopol-I was finally selected for in vivo skin irritation study. No significant difference in the values of erythema 
before and after the application of Carbopol-I was observed. Moreover, no apparent change on the surface of the skin ( $\mathrm{t}$-test, $\mathrm{p}=0.05$ ) was noticed that confirmed non-irritating effect of Carbopol-I to the skin of all volunteers.

\section{CONCLUSIONS}

The present study showed that Carbopol 934P based gel containing microemulsion of flurbiprofen had optimum thermodynamic stability, potential for in vitro permeation release rate and inhibition of inflammation. These properties can facilitate development of a cutting-edge strategy for transdermal delivery of flurbiprofen using innovative formulations of polymer based gel containing microemulsion.

\section{RESUMO}

O flurbiprofeno, potente anti-inflamatório não esteroidal, é amplamente utilizado no alívio da dor de pacientes que possuem doenças reumáticas, enxaqueca, dores de garganta e dismenorreia primária. Entretanto, apresenta muitos efeitos gastrointestinais indesejáveis quando administrado por via oral como hemorragia gástrica e úlcera péptica. Esses efeitos foram responsáveis por baixa adesão entre os pacientes, o que resulta no comprometimento do tratamento. As propriedades físico-químicas do flurbiprofeno fazem dele um candidato promissor para a administração transdérmica, que pode eliminar os inconvenientes causados durante a administração oral. Neste sentido, provou-se que as microemulsões aumentam a absorção cutânea de fármacos lipofílicos quando comparadas aos sistemas de liberação convencionais. O objetivo desse estudo foi desenvolver e caracterizar géis bases contendo microemulsões de flurbiprofeno. Diferentes géis bases contendo microemulsão e solução hidroalcoólica de flurbiprofeno foram desenvolvidos e comparados. Os estudos in vitro indicaram que os géis contendo microemulsão apresentaram velocidade de permeação superior ao géis contendo as soluções hidroalcoólicas. Adicionalmente, a formulação de Carbopol -I (microemulsão) apresentou maior capacidade de inibição da inflamação em relação às outras bases. Além disso, o estudo demonstrou que formulação de Carbopol -I (microemulsão) não ocasionou irritações cutâneas. Desta forma, o gel base de Carbopol -I contendo microemulsão de flurbiprofeno apresentou características físico-químicas, desempenho in vitro e in vivo adequados para o desenvolvimento de formulação alternativas de liberação transdérmica.

Palavras-chave: estudo de ação anti-inflamatória, flurbiprofeno, géis, permeação In vitro, microemulsões.

\section{ACKNOWLEDGMENTS}

We are thankful to Faculty of Pharmacy, The Islamia University Bahawalpur for providing financial assistance.

\section{REFERENCES}

Betageri G AND Prabhu S. 2007. Encyclopedia of pharmaceutical technology. In: Semisolid Preparations. USA: Informa Healthcare, $4370 \mathrm{p}$.

BNF - British National Formulary. 2006. 52, BMJ Publishing Group.

Chen H, Chang X, Du D, Li J, Xu H AND Yang X. 2006. Microemulsion based hydrogel formulation of ibuprofen for topical delivery. Int J Pharm 315: 52-58.

Chen H, Mou D, Du D, Chang X, Zhu D and LiU J. 2007. Hydrogel thickened microemulsion for topical administration of drug molecule at an extremely low concentration. Int J Pharm 341: 78-84.

DJORDJEVIC L, PRIMORAC M AND STUPAR M. 2005. In vitro release of diclofenac diethyl amine from caprylocaproyl macrogolglycerides based microemulsions. Int J Pharm 296: 73-79.

FANG J, HWANG T AND LEU Y. 2003. Effect of enhancers and retarders on percutaneous absorption of flurbiprofen from hydrogels. Int J Pharm 250: 313-325.

FouAd SA, BASALIOUS EB, EL-NABARAwI MA AND TAYEL SA. 2013. Microemulsion and poloxamer microemulsionbased gel for sustained transdermal delivery of diclofenac epolamine using in-skin drug depot: In vitro/in vivo evaluation. Int J Pharm 453: 569-578.

Hire N, Gudsoorkar V, Bhise K, Upasani C, NANDGUde T AND DALVI H. 2007. Microparticulate drug delivery system for topical administration of itraconazole. Asian $\mathrm{J}$ Pharm 1: 83-88.

IDRESS MA, RAHMAN NU, AHMAD S, Ali MY, AHMAD I. 2011. Enhance transdermal delivery of flurbiprofen via microemulsions: effects of different types of surfactants and cosurfactants. DARU J Pharm Sci 6: 433-439. 
KANTARCI G, OZGUNEY I, KARASULU Y, ARZIK S AND GUNERI T. 2007. Comparison of different water/oil microemulsions containing diclofenac sodium: preparation, characterization, release rate and skin irritation studies. AAPS Pharm Sci Tech 8: 91.

KhURANA S, JAIN N K AND BEDI PM. 2013. Nanoemulsion based gel for transdermal delivery of meloxicam: physicochemical, mechanistic investigation. Life Sci 92: 383-392.

Mishra A, RAVICHANDRAN V, JAIN PK, DiXIT VK AND AGRAWAL RK. 2008. Synthesis, characterization and pharmacological evaluation of amide prodrugs of flurbiprofen. J Braz Chem Soc 19: 89-100.

Nisha GS, VAishali P, Geeta R, Prabhakar P, Harish NM AND MARINA K. 2011. Formulation and evaluation of self micro-emulsifying drug delivery system of carbamazepine. Int J Res Pharm Sci 2: 162-169.

OECD - ORGANIZATION FOR ECONOMIC CO-OPERATION AND Development. 2004. Series on testing and assessment. Guidance document for the conduct of skin absorption studies.

OKUR NÜ, YAVAŞOĞLU A AND KARASUlU HY. 2014. Preparation and evaluation of micro-emulsion formulations of naproxen for dermal delivery. Chem Pharm Bull 62: 135-143.

Ozguney I, Karasulu H, Kantarci G, SOZER S, Guneri T AND ERTAN G. 2006. Transdermal delivery of diclofenac sodium through rat skin from various formulations. AAPS Pharm Sci Tech 7: 88.

Pellet M, Watkinson A, Brain K And Hadgraft J. 1997. Synergism between supersaturation and chemical enhancement in permeation through human skin. In: Brain KR, James VJ and Walter KA (Eds), Perspectives in Percutaneous Penetration. Cardiff: STS Publishing, p. 86.
Peltota S, KiesvaAra J And Suhonen T. 2003. Microemulsion for topical delivery of estradiol. Int J Pharm 254: 99-107.

RoESSLER B, WU H, RAMACHANDRAN C AND WEINAR N. 2001. Topical transport of hydrophilic compounds using water in oil nano-emulsions. Int J Pharm 220: 63-75.

Schachtel B, Aspley S, Shephard A, Shea T, Smith G, SANNER K, SAVINo L, REZUKE J AND SCHACHTEl E. 2014. Onset of action of a lozenge containing flurbiprofen 8.75mg: a randomized, double-blind, placebo-controlled trial with a new method for measuring onset of analgesic activity. Pain 155: 2422-2428.

SHAH S, RABBANI M AND AMIR F. 2006. Effect of urea on topical absorption of diclofenac diethylamine through hairless rabbit skin. J Res Sci 17: 165-171.

SIDDIQUI R, ENGLISH D AND CUI Y. 1995. Phorbal ester induced priming of superoxide degeneration by phosphatidic acid stimulated neutrophils and granule free neutrophil cytoplasts. J Leukoc Biol 58: 189-195.

TAN A AND BERRIDGE V. 2000. Superoxide produced by activated neutrophils efficiently reduces the tetrazolium salt, WST-1 to produce a soluble formazan: a simple colorimetric assay for measuring respiratory burst activation and for screening anti-inflammatory agents. J Immunol Methods 238: 50-68.

TrotTA M. 1999. Influence of phase transformation on indomethacin release from microemulsion. J Control Release 60: 399-405.

ZHU W, GUO C AND YU A. 2009. Microemulsion based hydrogel formulation of penciclovir for topical delivery. Int J Pharm 378: 152-158. 
